\title{
Domestic Investment, External Debt and Economic Growth: Cointegration and Causality Evidence from Nigeria.
}

\author{
Ibrahim Mohammed Adamu \& Rajah Rasiah \\ Faculty of Economics and Administration, University of Malaya, Malaysia \\ Email:mohdadamuibrahim@yahoo.com \\ DOI: https://doi.org/10.37134/jcit.vol7.1.2017
}

\begin{abstract}
This paper investigates the causal relationship between domestic investment, external debt and economic growth in Nigeria from 1970 to 2013. In doing so, we use the Bayer and Hanck, cointegration test and Granger causality tests, which is augmented with a lagged error correction term. The results reveal a unique and stable cointegrating relationship among the candidate variables. The results also show bidirectional causality flows among domestic investment, external debt, foreign direct investment and economic growth. In addition, the results demonstrate a unidirectional causality running from external debt to economic growth, and economic growth to domestic investment. Taken together, the results show that all the four variables have a complementarity relationship with one another, and influence economic growth in Nigeria.
\end{abstract}

Keywords Domestic investment, External debt, FDI, Economic growth

\section{Introduction}

While domestic investment is often considered as a noteworthy component of economic growth, the question of whether external debt and foreign direct investment play a significant role remains contentious. Conventionally, external borrowing has become one of the major source of capital for developing countries, mainly to equate deficits between domestic savings and investment in order to promote growth (Schmidt-Hebbel et al., 1994; Chenery and Strout, 1966; Nurkse, 1963). It is also justified on the ground that developing countries, particularly the low income countries lack sufficient capital, instead, they largely depend on external capital to finance development programmes (Bosworth, et al., 1999). It is assumed that if the borrowed funds are fully utilized to finance productive activities, would support domestic investment and enhance long run economic growth.

Besides external borrowing, developing countries have benefitted from foreign direct investment, which promotes physical capital through its linkages with trade and technological capabilities (Rasiah, 2005). This would increase the marginal product of capital in productive sectors and encourage new investment commitment until the capital-labour ratio, wages and capital are equalized simultaneously (Saggi, 2000; Sadiq and Bolbol, 2001; Caselli and Feyrer, 2007). Also, foreign direct investment is a key component of globalization and integration of the global economy for employment creation and transfer of technological know how for increasing productivity, and ultimately enhances output growth (Anyanwu, 2012).

The contribution of the present paper is threefold: First, to the best of our knowledge, this is the first attempt to investigate the causal relationship between domestic investment and economic growth by incorporating external debt and foreign direct investment simultaneously in the Nigerian context. This is based on the notion that both external debt and foreign direct 
investment are forms of capital flows that can yield significant benefit and promote growth through their impact on domestic investment in developing countries (Neuman, 2003). Second, with regard to methodology, the paper employs a more recent combine cointegration tests developed by Bayer and Hanck (2013), to explore the cointegrating relationship among the variables. This will provide a robust cointegrating relation over other cointegration tests such as Johansen and Juslius (1990) and Engle and Granger (1987). Third, the application of VECM Granger causality test may provide a clear understanding of the causal effects among the variables, which would assist policy makers in planning for a comprehensive economic policy package for a viable investment and long term economic growth.

To that end, this study seeks to provide a clear understanding on the causal relationship between domestic investment, external debt, foreign direct investment and economic growth in Nigeria. To carry out this, we employ a time series data spanning from 1970 to 2013. Following the introduction, the rest of the paper is organized as follows: Section 2 provides a review of the related literature while methodology is discussed in section 3 . Section 4 presents empirical results and discussion and section 5 concludes the paper.

\section{Literature}

This section reviews the empirical literature relevant to the field of study. Based on the survey of literature, there are relatively few studies that empirically examine the causal relationship between domestic investment, external debt, foreign direct investment or economic growth. The importance of domestic investment in promoting economic growth through alternative financing sources such as external debt and foreign direct investment cannot be overemphasized. It is generally believed that economic growth can take place with adequate investment in capital formation and other exogeneous component, therefore, the question of causal relationship between domestic investment and economic growth is not a recent debate among researchers (Blomstrom et al., 1993). For example, Ezirim et al., (2006) explored the causal relationship between external debt and foreign direct investment using modified Granger causality for Nigeria over the period 1970 through 2001. They found a bidirectional causality between external debt and foreign direct investment, but both variables are unable to promote output growth in Nigeria. Tang et al., (2008) used quarterly time series data in China from 1988 to 2003 to investigate the causal linkages between FDI, domestic investment and economic growth. The empirical results indicate a bidirectional causality between domestic investment and economic growth, and a unidirectional causality running from FDI to domestic investment, and to economic growth. Thus, FDI is found to be complementary with domestic investment and economic growth.

Ullah et al., (2014) examined the interaction between domestic investment, foreign direct investment and economic growth in Pakistan spanning from 1976 to 2010. The empirical results confirmed a cointegrating relation among the variables. The study observed a bidirectional causality between FDI and domestic investment. Similarly, the study found a unidirectional causality flows from domestic investment to economic growth and economic growth to FDI. Using a trivariate model in Malaysia from 1970 to 2009, Lean and Tan (2011) investigated the linkages between foreign direct investment, domestic investment and economic growth. In the short run, they found unidirectional causality running from economic growth and domestic investment to foreign direct investment, whereas in the long run only 
foreign direct investment equation is significant indicating that FDI causes domestic investment and economic growth.

Turning to panel data studies, Apergis et al., (2006) examined the relationship between FDI and domestic investment for 30 developing countries from 1992 to 2002, and found unidirectional causality running from FDI to domestic investment. Using heterogeneous panel data analysis in 31 developing countries, Hansen and Rand (2006) found a bidirectional causality between foreign direct investment and economic growth. Using a panel VAR approach, Choe (2003) investigates the causal relationships between economic growth, FDI and gross domestic investment in 80 developing countries from 1971 to 1995 . The results reveal a bidirectional causality between FDI and economic growth. Similarly, a unidirectional causality was observed from economic growth to gross domestic investment.

Following the review of the empirical literature, this study noticed that the majority of the studies, while investigating the causal relations, they either used domestic investment, FDI and economic growth (see, Choe, 2003; Tang et al., 2008; Ullah et al, 2014; Lean and Tan, 2011), domestic investment and economic growth (see, Hansen and Rand, 2006; Apergis et al., 2006), or external debt and domestic investment (see, Ezirim et al., 2006). However, none of the existing studies incorporate all the variables simultaneously in a single model to examine their causal relations. Therefore, this study attempt to bridge this existing gap in the literature.

\section{Methodology}

This section describes the appropriate methodology to be used for a robust estimation of the results. We discuss the data followed the different tests that will be administered to establish causality.

\subsection{Data}

The study employs annual time series data on domestic investment (DI), external debt (ED), foreign direct investment (FD) and economic growth (GR) for Nigeria over the period 1970 to 2013. The sample period is chosen based on the availability of data. Since macroeconomic time series data are naturally trending over time, Luktepohl (2004) and Juselius et al., (2011) suggests that the transformation of data into a log form will reduce the inconsistencies in data. The description and sources of data are shown in Table 1.

Table 1 Definition of variables and sources of data

\begin{tabular}{lll}
\hline Code & Definition & Data source \\
\hline $\ln D I$ & $\begin{array}{l}\text { Log of domestic investment (proxy ratio of gross } \\
\text { capital fixed formation to GDP) }\end{array}$ & $\begin{array}{l}\text { World Macroeconomic Research; World } \\
\text { Development Indicators, World Bank }\end{array}$ \\
$\ln E D$ & Log of ratio of external debt to GNI & World Development Indicators, World \\
& & Bank \\
$\ln F D$ & $\begin{array}{l}\text { Log of ratio of foreign direct investment Inflow to } \\
\text { GDP }\end{array}$ & $\begin{array}{l}\text { World Development Indicators, World } \\
\text { Bank }\end{array}$ \\
$\ln G R$ & Log of real per capita GDP & $\begin{array}{l}\text { World Development Indicators, World } \\
\text { Bank }\end{array}$
\end{tabular}




\subsection{Unit root test}

Testing the order of integration in time series data studies has become an integral part of economic research in recent times. This is aimed at getting statistical tools for analysis consistent with a seeming data generating process of macroeconomic time series (Carrion-ISilvestre and Sanso, 2005). Failure of the stationarity tests of the series could lead to spurious conclusion (Engle and Granger, 1987). In order to examine the order of integration of the series, this study used two conventional unit root tests, namely - Augmented Dickey Fuller (ADF) test (Dickey and Fuller, 1979, 1981) and Phillips-Perron (PP) test (Phillips and Perron, 1988).

\subsection{Cointegartion test}

Having confirmed the order of integration of the variables, the next is to estimate the long run cointegrating relationship among the variables. A number of cointegration tests have been in used such as Engle and Granger (1987) and Johanson and Juselius (1990), however, no one among them is appropriate to provide a robust and reliable results in all tests (Gregory et al., 2004). In this case, this study employs the joint test statistics for the null of non-existence of cointegration based on Engle and Granger, Johansen, Peter Boswijk, and Banajee test, which termed as combine cointegration tests developed by Bayer and Hank (Bayer and Hanck, 2013). This recent cointegration test approach provides different cointegration tests for each particular model which gives a robust conclusive result over the conventional cointegration method. The Bayer-Hanck (2013) test calculated the level of significance of each cointegration test in the Fisher's formulas as specified:

$$
\begin{aligned}
& E G-J O H=-2[\ln (P E G)+(P J O H)] \\
& E G-J O H-B O-B D M=-2[\ln (P E G)+(P J O H)+(P B O)+(P B D M)]
\end{aligned}
$$

where $P E G, P J O H, P B O$ and $P B D M$ represents the probability values of different model cointegration tests. The assumption is that if the estimated Fisher statistics is greater than the critical values developed by Bayer and Hanck (2013), we can conclude that the null hypothesis of no cointegration is rejected.

\subsection{Granger causality test}

The concept of causality that has been widely used in the econometrics studies was first introduced by Wiener (1956) and popularize by Granger (1969). Theoretically, causality describes that a variable $X_{t}$ to be causal for a variable $Y_{t}$ if the past values of $X_{t}$ can help in predicting the forecast value of $Y_{t}$. Engle and Granger (1987) also developed a standard causality test with an augmented lagged error correction term. They stated that causality can exist in at least one direction (Uni-directional causality), or both (Bi-directional causality) in the presence of cointegrating relation among the variables, that share common stochastic trend and are integrated of order one process i.e. I(1) (Granger, 1988). In addition, he warned that if the Granger causality test is examined using the $I(1)$ and vector autoregression process, then it will be a misguiding when a cointegrating relationship exists. Hence, an inclusion of another variable to the vector autoregression process like the error correction term could assists to 
check for the long run relationship. Thus, the augmented Granger causality test in the vector error correction model (VECM) framework can be in the following form:

$$
(1-L)\left[\begin{array}{l}
X_{t} \\
Y_{t}
\end{array}\right]=\left[\begin{array}{l}
\delta_{1} \\
\delta_{2}
\end{array}\right]+\sum_{i=1}^{k}(1-L)\left[\begin{array}{l}
\alpha_{11}(L) \alpha_{12}(L) \\
\alpha_{21}(L) \alpha_{22}(L)
\end{array}\right]+\left[\begin{array}{l}
\lambda_{1} \\
\lambda_{2}
\end{array}\right] E C T_{t-1}+\left[\begin{array}{l}
\mu_{1} \\
\mu_{2}
\end{array}\right]
$$

where $(1-L)$ is a difference operator, $i(i=1, \ldots, k)$ is the optimum lag determined by the Akaike Information Criteria (AIC), $E C T_{\mathrm{t}-1}$ stand for the lagged error correction term for the long run cointegrating relationship using the autoregressive distributed lag model, $\lambda(i=1,2)$ is the intercept and $\mu_{1}$ and $\mu_{2}$ are the serially stochastic error term with zero mean and finite covariance matrix. Consequently, using the error correction term (ECT), the vector error correction model (VECM) establishes the new directions for Granger causality. Meanwhile, the long run causality is also provided through the significance of the one period lagged of ECT's using $t$-statistics, whereas for the short run causality, the results are attained through the Wald test (F-statistics).

\section{Results and Discussion}

This section presents the estimated results and discussion.

\subsection{Unit root test results}

Table 2 reports the results of the unit root tests using the natural logs of the series in their level and first difference form. As can be seen from the results, all the variables under investigation are not stationary at level, i.e. $I(0)$, but become stationary after the first difference, i.e. $I(1)$ order of integration. This indicates that none of the variables have proven to be $I(0)$, therefore, we concluded that all the variables are integrated of order one i.e. I(1) process. This paves the way to the test of the long run cointegrating relation among the variables.

Table 2 Unit root tests

\begin{tabular}{|c|c|c|c|c|c|}
\hline \multirow[t]{2}{*}{ Variable } & \multicolumn{3}{|l|}{ ADF } & \multicolumn{2}{|l|}{ PP } \\
\hline & At Level & & At $1^{\text {st }}$ difference & At Level & At $1^{\text {st }}$ difference \\
\hline $\ln D I_{t}$ & $-2.366(0)$ & & $-6.642(1)^{* * *}$ & $-2.545(1)$ & $-6.623(9)^{* * *}$ \\
\hline $\ln E D_{t}$ & -0.702 & (0) & $-5.395(0)^{* * *}$ & $-0.766(3)$ & $-5.315(6)^{* *}$ \\
\hline $\ln F D_{t}$ & -1.796 & (1) & $-10.717(0)^{* * *}$ & $-3.123(1)$ & $-11.523(7)^{* * *}$ \\
\hline $\ln G R_{t}$ & -1.962 & (0) & $-6.157(0)^{* * *}$ & -1.988 & $-6.157(1)^{* * *}$ \\
\hline
\end{tabular}

Note: ${ }^{* * *},{ }^{* *}$ and $^{*}$ indicate $1 \%, 5 \%$ and $10 \%$ significance level respectively. Constant and the trend was included. An automatic maximum lag is used by the Akaike Inion Criterion (AIC) for ADF, and Newey-west bandwidth using Bartlett kernel for PP tests. The figures in brackets (...) denote the number lag selected. 


\subsection{Cointegration test results}

Once the stationarity of variables is confirmed, the next step is to estimate the existence of a cointegrating relationship among the four variables under investigation. As earlier proposed, the combined cointegration test (Bayer and Hanck, 2013) is used by interchanging each independent variable as the dependent variable. Table 4 reports the cointegrating results, which comprises of EG-JOH and EG-JOH-BO-BDM tests. From the Table, we can observe that the calculated Fishers statistics of 16.530, 30.261 and 135.191 for domestic investment, external debt and economic growth equations are greater than the $10 \%, 5 \%$ and $1 \%$ critical values for EG-JOH and EG-JOH-Ba-BDM, hence, there is three cointegrating vectors, which indicate a stable long run relationship among the variables.

Table 3 Bayer and Hanck combine cointegration results

\begin{tabular}{llll}
\hline Equation & EG-JOH & EG-JOH-BO-BDM & Inference \\
\hline$D I_{t}=f\left(E D_{t}, F D_{t}, G R_{t}\right)$ & 12.404 & $16.530^{*}$ & Cointegration \\
$E D_{t}=f\left(D I_{t}, F D_{t}, G R_{t}\right)$ & 12.502 & 15.051 & No cointegration \\
$F D_{t}=f\left(D I_{t}, E D_{t}, G R_{t}\right)$ & 13.807 & $30.261^{* *}$ & Cointegration \\
$G R_{t}=f\left(D I_{t}, E D_{t}, F D_{t}\right)$ & 24.667 & $135.191^{* * *}$ & Cointegration \\
\hline Level of significance & Critical values & Critical values & \\
\hline $1 \%$ level & 16.259 & 31.169 & \\
$5 \%$ level & 10.637 & 20.486 & \\
$10 \%$ level & 8.363 & 16.097 & \\
\hline Note: ${ }^{* * *}{ }^{* *}{ }^{* *}$ indicates significance at $1 \%, 5 \%$ and $10^{*} \%$ level respectively. & \\
\hline
\end{tabular}

Note: ${ }^{*},{ }^{* *}$ and ${ }^{* *}$ indicates significance at $1 \%, 5 \%$ and $10 \%$ level respectively.

\subsection{VECM Granger causality tests results}

Once all the variables are integrated of order one, $I(1)$, and given that the Bayer and Hanck combine cointegration tests suggest that domestic investment(DI), external debt (ED), foreign direct investment (FD) and economic growth (GR) are cointegrated, then Granger causality test based on VECM framework can be constructed. This is by taking each of the variable serve as dependent variable, this would allow us to examine the short run and long run Granger causality to identify the direction of causality among variables using Wald test that stemmed from co-integrating results, and it is conducted in a multivariate $p^{\text {th }}$ order of the VECM which is specified as:

$$
(1-L)\left[\begin{array}{c}
\Delta \ln D I_{t} \\
\Delta \ln E D_{t} \\
\Delta \ln F D_{t} \\
\Delta \ln G R_{t}
\end{array}\right]=\left[\begin{array}{c}
\alpha_{1} \\
\alpha_{2} \\
\alpha_{3} \\
\alpha_{4}
\end{array}\right]+\sum_{i=1}^{P}(1-L)\left[\begin{array}{l}
\psi_{11, i} \psi_{12, i} \psi_{13, i} \psi_{14, i} \\
\psi_{21, i} \psi_{22, i} \psi_{23, i} \psi_{24, i} \\
\psi_{31, i} \psi_{32, i} \psi_{33, i} \psi_{34, i} \\
\psi_{41, i} \psi_{42, i} \psi_{43, i} \psi_{44, i}
\end{array}\right]+\left[\begin{array}{c}
\lambda_{1} \\
\lambda_{2} \\
\lambda_{3} \\
\lambda_{4}
\end{array}\right] E C T_{t-1}+\left[\begin{array}{c}
\varepsilon_{1 t} \\
\varepsilon_{2 t} \\
\varepsilon_{3 t} \\
\varepsilon_{4 t}
\end{array}\right]
$$

All variables are defined earlier. Where $(1-L)$ is the difference operator, $E C T_{t-1}$ indicates the lagged residual of the cointegration equations, $\varepsilon_{1 t}$ to $\varepsilon_{4 t}$ are the stationary residuals, which 
are serially independent random errors with mean zero and finite covariance matrix. The confirmation of the long run equilibrium relationship in the first difference of the variables, supports the existence of short run causality using the $p$-values, while the long run causality is indicated by the significance of the $t$-statistics of the error correction term. The optimal lag length for the VECM is selected based on Akaike Information Criterion (AIC).

Table 4 reports the VECM Granger causality/Block exogeneity Wald tests. To begin with the short run causality ( $\chi^{2}$ statistics). In the domestic investment equation, a unidirectional causality is observed from external debt, foreign direct investment and economic growth to domestic investment. This is consistent with findings by Tang et al., (2008); Lean and Tan (2011); Apergis et al., (2006). External debt equation, also causality runs from domestic investment to external debt, which implies that Nigerias quest for the investment in infrastructure development projects has trigger the demand for external finances, which stimulate output growth. For foreign direct investment equation, causality runs from domestic investment, economic growth to foreign direct investment, whereas in the economic growth equation, domestic investment, external debt and foreign direct investment Granger cause economic growth. Similarly, unidirectional causality runs from external debt to economic growth, and economic growth to public investment. This result validates our conclusion of the short run complementarity effects among of public investment, external debt, economic growth and foreign direct investment.

Meanwhile, we observed a bidirectional causality between external debt and economic growth, domestic investment and foreign direct investment, foreign direct investment and economic growth, and domestic investment and economic growth. This implies that both variables are simultaneously complementing each other. These results are consistent with findings by Ezirim et al., (2006), Ullah et al., (2014), Choe (2003); Tang et al., (2008), and Hansen and Rand (2006). Turning to long run causality, except external debt equation, a long run causality is observed in the investment, economic growth and foreign direct investment equations. This indicates that the one period error correction terms are significant, which also support the Bayer and Hanck combine cointegration results, thus, implying that the combine variables Granger cause investment, economic growth and foreign direct investment in the long run in Nigeria.

\begin{tabular}{|c|c|c|c|c|c|}
\hline \multirow{3}{*}{$\begin{array}{l}\text { Dependent } \\
\text { variable }\end{array}$} & \multicolumn{5}{|c|}{ Short run causality } \\
\hline & \multicolumn{4}{|c|}{$\chi^{2}$ statistics of lagged first difference term ( $p$-value) } & \multirow{2}{*}{$\begin{array}{l}\text { Long run causality } \\
\text { ect } t_{t-1}\end{array}$} \\
\hline & $\sum \Delta \ln D I$ & $\sum \Delta \ln E D_{t}$ & $\sum \Delta \ln F D_{t}$ & $\sum \Delta \ln G R_{t}$ & \\
\hline \multirow[t]{2}{*}{$\Delta \ln D I_{t}$} & ---- & 20.667 & 19.253 & 11.943 & -1.506 \\
\hline & & $(0.000)^{* * *}$ & $(0.001)^{* * *}$ & $(0.035)^{*}$ & {$[-5.284]^{* * *}$} \\
\hline \multirow[t]{2}{*}{$\Delta \ln E D_{t}$} & 10.127 & ---- & 0.989 & 1.781 & -0.187 \\
\hline & $(0.071)^{*}$ & & $(0.963)$ & $(0.878)$ & {$[-0.375]$} \\
\hline \multirow[t]{2}{*}{$\Delta \ln F D_{t}$} & 14.670 & 10.138 & ---- & 12.950 & 0.573 \\
\hline & $(0.002)^{* * *}$ & $(0.071)$ & & $(0.072)^{* *}$ & {$[2.34]^{* *}$} \\
\hline \multirow[t]{2}{*}{$\Delta \ln G R_{t}$} & 14.379 & 11.856 & 10.098 & -- & -1.479 \\
\hline & $(0.003)^{* * *}$ & $(0.036)^{* *}$ & $(0.072)^{*}$ & & {$[-1.755]^{*}$} \\
\hline
\end{tabular}


Note: ${ }^{* * * * *}$ and ${ }^{*}$ indicate $1 \%, 5 \%$ and $10 \%$ significance level respectively. $p$-values in parenthesis ( $\left.\ldots\right)$ and the figure in square bracket $[\ldots]$ indicate $t$-statistics.

\section{Conclusion}

The paper explores a multivariate causal relationship between domestic investment, external debt, foreign direct investment and economic growth in Nigeria covering the period 1970 to 2013. The empirical results suggest the existence of both unidirectional and bidirectional causal relationship among the variables. Similarly, our findings show that the flow of both external debt and FDI in Nigeria over the study period have stimulated economic growth through their impact on domestic investment. The findings of this study are limited to Nigeria and to other countries that share similar economic, social, political institutions.

For Nigeria the empirical results offer serious policy implications. First, given that domestic investment through external finances provides an outstanding contribution to the growth of output, Nigeria should double efforts to ensure that borrowed funds are utilized in productive domestic investment with a higher rate of return that would repay the debt. Because of the countries experienced, findings have shown that inappropriate management of the borrowed funds have been the reasons for the debt crisis in most of the developing countries, which crowd out investment and affect growth negatively (clement et al., 2003; Adamu and Rajah, 2015). Second, government should provide an enabling policy environment for both domestic and foreign investment to exist, this will assist in shaping the phase for long term economic growth. To advance the current research topic, a multivariate Granger causality test can also examine using the same framework on panel data analysis. Furthermore, other variables such as private investment, aid flows, which was overlooked in this study can also incorporated to determine their causal effect.

\section{References}

Adamu, I.M., \& Rasiah, R. (2015). External debt financing of public capital formation: Empirical evidence from Nigeria. In VGR. C, Govindaraju, M., Nourani, K.S.J., Singh, M.A, Mia \& Mubarik S. (Eds.), Promoting Growth, Excellence and Sustainability. Paper presented at the postgraduate conference on Economics, Public administration and Business organised by Faculty of Economics and Administration, University of Malaya, 5th September, 2015, 456-465. Kuala Lumpur, Malaysia.

Anyanwu, J.C. (2012). Why does foreign direct investment go where it goes? New evidence from African countries. Annals of Economics and Finance, 13(2), 425-462.

Apergis, N., Katrakilidis, C.P., \& Tabakis, N.M. (2006). Dynamic linkages between FDI inflows and domestic investment: A panel cointegration approach. Atlantic Economic Journal, 34.

Bayer, C., \& Hanck, C. (2013). Combining non-cointegration tests. Journal of Time series analysis, 34(1), 83-95.

Blomstrom, M., Lipsey, R.E., \& Zejan, M. (1993). Is fixed investment the key to economic growth? (NBER Working paper No. 4436). Massachusetts: National Bureau of Economic Research.

Bosworth, B.P., Collins, S.M., \& Reinhart, C.M. (1999). Capital flows to developing economies: Implications for saving and investment. Brookings Papers on Economic Activity, 1999(1), 143-180.

Carrion-i-Silvestre, J.L., \& Sanso, A. (2005). A guide to the computation of stationarity tests. Empirical Economics, 31, 433-448.

Caselli, F., \& Feyrer, J. (2007). The marginal product of capital. The Quarterly Journal of Economics, 122(2), 535-568.

Chenery, H.B., \& Strout, A. (1966). Foreign assistance and economic development. American Economic Review, 56(4), 679-733.

Choe, J. I. (2003). Do foreign direct investment and gross domestic investment promote economic growth? Review of Development Economics, 7(1), 44-57. 
Clements, B., Bhattarcharya, R., \& Nguyen, T.Q. (2003). External debt, public investment, and economic growth in low income countries (No. 03/249). Washington, D.C.: International Monetary Fund.

Dickey, D.A., \& Fuller, W.A. (1979). Distributions of the estimators for autoregressive time series with a unit root. Journal of American Statistical Association, 74(366), 427-481.

Dickey, D.A., \& Fuller, W.A. (1981). Likelihood ratio statistics for autoregressive time series with a unit root. Econometrica, 49(4), 1057-1072.

Engle, R.F., \& Granger, C.W.J. (1987). Co-integration and error correction: representation, estimation, and testing. Econometrica, 55(2), 251-276.

Eshaq, E. (1983). Fiscal and Monetary Policies and Problems in Developing Countries. Cambridge, United Kingdom: Cambridge University Press.

Ezirim, C.B., Anoruo, E., \& Muoghalu, M.I. (2006). The impact of external debt burden and foreign direct investment remittances on economic growth: An Empirical evidence from Nigeria. African Economic and Business Review, $4(1), 25-47$.

Granger, C.W.J. (1969). Investigating causal relations by econometric models and cross-spectral methods. Econometrica, 37(3), 424-438.

Granger, C.W.J. (1988). Developments in the study of cointegrated economic variables. Oxford Bulletin of Economics and Statistics, 48, 213-228.

Gregory, A.W., Haug, A.A., \& Lomuto, N. (2004). Mixed signals among tests for cointegration. Journal of Applied Econometrics, 19(1), 89-98.

Hansen, H., \& Rand, J. (2006). On the causal links between FDI and growth in developing countries. The World Economy, 29(1), 21-41.

Johansen, S., \& Juselius, K. (1990). Maximum likelihood estimation and inference and cointegration with application to the demand for money. Oxford Bulletin of Economics and Statistics, 52(2), 169-2010.

Lean, H.H., \& Tan, B.W. (2011). Linkages between foreign direct investment, domestic investment and economic growth in Malaysia. Journal of Economic Cooperation and Development, 32(4), 75-96.

Lutkepohl, H. (2004). Univariate time series analysis. In Lutkepohl, H., \& Kratzig, M. (Eds.). Applied Time Series Econometrics. Cambridge, United Kingdom: Cambridge University Press.

Neumann, R.M. (2003). International capital flows under asymmetric information and costly monitoring: Implications of debt and equity financing. Canadian Journal of Economics, 36(3), 674-700.

Nurkse, R. (1963). Problems of Capital Formation in Underdeveloped Countries. London, United Kingdom: Oxford University Press.

Phillips, P., \& Perron, P. (1988). Testing for a unit root in time series regression. Biometrica, 75(2), 335-346.

Rasiah, R. (2005). Trade-related investment liberalization under the WTO: The Malaysian experience. Global Economic Review, 34(4), 453-471.

Sadiq, A.T., \& Bolbol, A.A. (2001). Capital flows, FDI, and technology spillovers: Evidence from Arab countries. World Development, 29(12), 2111-2125.

Saggi, K. (2000). Trade, foreign direct investment, and international technology transfer: A survey (Policy Research Working paper No. 2349). Washington, D.C.: The World Bank.

Schemidt-Hebbel, K., Serven, L., \& Solimano, A. (1994). Saving, investment, and growth in developing countries: An overview (Macroeconomic and Growth Division No. 1382/1994). Washington, D.C.: The World Bank.

Tang, S., Selvanathan, E.A., \& Selvanathan, S. (2008). Foreign direct investment, domestic investment and onomic growth in China: A time series analysis (UNU-WIDER No. 2008/19). Finland: United Nation University.

Ullah, I., Shah, M., \& Khan, F.U. (2014). Domestic investment, foreign direct investment, and economic growth nexus: A case of Pakistan. Economics Research International, 2014, 1-5.

Wiener, N. (1956). The theory of prediction. In Beckenbach, E. (Eds.), Modern Mathematics for Engineers. New York: McGraw-Hill. 